\title{
MANAJEMEN PENCITRAAN DI MADRASAH BERPRESTASI (MADRASAH ALIYAH NEGERI BANGIL DAN MADRASAH ALIYAH NEGERI KRATON PASURUAN)
}

\author{
Anas Suprapto \\ e-mail: anassuprapto2073@gmail.com \\ Kementerian Agama Kabupaten Pasuruan
}

Abstract

Madrasah today becomes one of the people's choices. There were changes in the perception of the educational institutions (madrasah) from "under-estimate" by most people to be sympathetic and believe in the existence and madrasah education services. Neverthelees, not all the madrasah to make progress as part of a planned and professionally managed. Professional management is one indicator is entering the marketing strategy of its reality madrasah included in this komodity.This study region focuses on: 1. Aspects of the underlying imaging management 2. Management pattern imaging performed and 3. Implementation imaging management in realizing the madrasah who excel in MAN Bangil and MAN Kraton. This study used a qualitative approach, case study with a design multisite.Technics ofdata collection is done in three ways, namely: 1. Observation 2. In-depth interviews; and 3. Documentation. Existing data were analyzed through two stages: 1 . Analysis of data on individual case and2. Analysis of data across sites (cross-site analysis). Sources of data in this research is the headmaster, the deputy headmaster, teachers, committees, students, school administration staff, gardener, and citizens around the madrasah.

The results showed that: first, the underlying aspects of management among other related imaging madrasah; madrasah vision, mission, background / history of the madrasah, the tendency of the public mindset, opportunities for madrasah to be an option. Second, the pattern of imaging in both MAN management is no conformity with the marketing approach of BPD (branding, positioning and differentiating). Both madrasah underlying the strategy by promoting religious culture as mainstream. Third, the implementation is done by utilizing imaging management and maximize the role of the media, activities that direct access to the community, and to fuse the cultures existing society. The findings of this study is madrasah has the potential to remain an option because it has the values of the peculiarities of the religious culture. Approach to marketing is done in order to answer the demands of public order madrasah can adjust to market needs.

Keywords: imaging management, the school achievement, madrasah aliyah

\section{Abstrak}

Madrasah dewasa ini menjadi salah satu pilihan masyarakat. Terjadi perubahan persepsi terhadap lembaga pendidikan (madrasah) dari "underestimate"oleh sebagian besar masyarakat menjadi simpati dan percaya dengan keberadaan dan layanan pendidikan madrasah. Kendati demikian, belum semua madrasah menjadikan kemajuan tersebut sebagai bagian yang direncanakan dan dikelola secara profesional. Pengelolaan secara professional ini salah satu indikatornya adalah memasukkan strategi marketing karena realitasnya madrasah masuk dalam wilayah komoditas.Penelitian ini memfokuskan pada : 1. Aspek yang melandasi manajemen pencitraan 2. Pola manajemen pencitraan yang dilakukan, dan 3 . Implementasi manajemen pencitraan dalam mewujudkan madrasah yang berprestasi 
di MAN Bangil dan MAN Kraton. Penelitian ini menggunakan pendekatan kualitatif, jenis penelitian studi kasus dengan rancangan multisitus. Teknik pengumpulan data dilakukan dengan tigacara, yaitu: 1. Observasi (observation); 2. Wawancara mendalam (interview); dan 3. Dokumentasi (dokumentasi). Data yang ada dianalisa melalui dua tahap, yaitu : 1. Analisa data kasus individu (individual case); dan 2. Analisa data lintassitus (cross-situs analysis). Sumber data dalam penelitian ini adalah kepala madrasah, wakil kepala madrasah, guru, komite, siswa, staf TU, tukang kebon, dan warga sekitar madrasah.

Hasil penelitian menunjukkan bahwa : pertama, aspek yang mendasari manajemen pencitraan madrasah antara lain terkait visi misi madrasah, latar belakang/sejarah madrasah, kecenderungan pola piker masyarakat, dan peluang bagi madrasah untuk menjadi pilihan. Kedua, pola manajemen pencitraan di kedua MAN ada kesesuaian dengan pendekatan marketing BPD (branding, positioning, dan differentiating). Kedua madrasah mendasari strategi tersebut dengan mengedepankan kultur religious sebagai mainstreamnya. Ketiga, implementasi manajemen pencitraan dilakukan dengan memanfaatkan dan memaksimalisasi peran media, kegiatan yang berakses langsung dengan masyarakat, serta berfusi pada kultur budaya masyarakat yang ada. Temuan penelitian ini adalah madrasah memiliki potensi untuk tetap menjadi pilihan karena memiliki nilai-nilai kekhasan yaitu kultur religius. Pendekatan marketing dilakukan dalam rangka menjawab tuntutan publik agar madrasah dapat menyesuaikan dengan kebutuhan pasar.

Kata kunci: manajemen pencitraan, madrasah berprestasi, madrasah aliyah

\section{Pendahuluan}

Madrasah dewasa ini menjadi salah satu alternatif pilihan pendidikan bagi masyarakat.Sejalan dengan pergeseran pola fikir dan paradigma akan dunia pendidikan, maka terjadi perubahan persepsi terhadap pendidikan di madrasah. Pergeseran pandangan dari "under estimate" oleh sebagian besar masyarakat menjadi simpati dan percaya dengan keberadaan dan layanan pendidikan madrasah.

Dalam teori manajemen, membangun "image"(pencitraan)

merupakan salah satu bagian menjaga persepsi yang tidak terpisahkan dari strategi "marketing", dimana usaha-usaha yang dilakukan berjalan secara berkesinambungandalam hal pengenalan lembaga beserta produk-produknya, baik melalui iklan, doktrin langsung ke konsumen, dan berbagai cara lainnya. Reputasi diperolehdarisebuah upaya yang tidak tiba-tiba dan tidak bisa direkayasa, dimana esensi pencitraaan bagi institusi adalah dalam rangka repositioningdan merebut pangsa pasar.
Citra menurut Kamus Besar Bahasa Indonesia diberikan pengertian sebagai berikut ; 1). kata benda ; gambar, rupa, gambaran, 2). gambaran yang dimiliki orang banyak mengenai pribadi, perusahaan, organisasi atau produk, 3). kesan mental atau bayangan visual yang ditimbulkan oleh sebuah kata, frase atau kalimat, dan merupakan unsur dasar yang khas dalam karya prosa atau puisi, 4). data atau informasi dari potret udara untuk evaluasi (Kamus Besar Indonesia, 1994: 239).

Citra dalam konteks strategi lembaga sebagai proses "corporate image management" (manajemen pencitraan lembaga) atau dengan istilah strategi komunikasi dan pandangan publik. Oleh karenanya citra, sebagaimana pendapat Kotler, 2000: 553).:

....image is the set of believes,ideas, and impressions a person hald regarding an object. Peopels attitude and action to ward an object are higly conditioned by that object image . 


\author{
Menurut Nimmo, citra adalah segala \\ hal yang berkaitan \\ dengansituasikeseharianseseorang;menya \\ ngkutpengetahuan,perasaan
}

dankecenderungannya terhadap sesuatu. Citra dapat berubah seiringdengan perjalanan waktu. Teorimage buildingmenyebutkan bahwa, citra akan terlihat atau terbentuk melalui proses penerimaan secara fisik (pancaindra), masuk ke saringan perhatian (attention filter), dan dari situ menghasilkanpesan yang dapat dilihat dan dimengerti (perseived message), yang kemudianberubah menjadi persepsi dan akhirnya membentuk citra (Nimmo 2006:204). Pandangan tersebut sejalan denganKazoleas(an International Journal,2001:19 menyatakan bahwa ;

...an image is a perception of a receiver of his or her received projection of the corporate identity and own reflection of interpretations of various attributes from various source.It is a complex of cognitive interpretations that members of the key publics hold of an organization.

Pengertian tersebut dapat disimpulkan bahwa suatu citra adalah persepsi dari seorang penerima berdasarkan pertimbangan yang dimiliknya terhadap identitas perusahaan dan daya reflek interpretasi yang kompleks dimana masyarakat merasa berkepentingan terhadap sebuah organisasi. Sedangkan, menurut JohnChistieJohn Cristie (1993: 82) menyatakanberikut ini

corporate image as what the organization transmits to its receiversabout it self and howthese projections are received

Madrasah yang memiliki citra baik adalah Madrasah Aliyah Negeri (MAN) Bangil dan Madrasah Aliyah Negeri (MAN) Kraton. Kedua madrasah tersebut di atas berada dalam wilayah kabupatenPasuruan Jawa Timur.Walaupun berada di alokasi yang berbeda tetapi masih dalam satu wilayah kabupaten, masing-masing memiliki latar belakang sejarah yang sama (MAN Bangil bermula dari yayasan dan MAN Kraton merupakan madrasah pesantren yang dinegerikan), basis masyarakat Islam yang kuat, posisi teritorial dan masing-masing memiliki program yang diunggulkan.

Madrasah merepresentasikan lembaga pendidikan berbasis keagamaan dengan dukungan masyarakat yang variatif, berada dalambudaya masyarakat dengankomunitas sosial keagamaan yang beragam. Fenomena MAN Bangil sebagai salah satu madrasah dengan jumlah siswa yang sangat besardan memiliki sejarah berdiri yang menarik. Kesan sebagai lembaga pendidikan agama yang cukup megah dan terus berbenah secara fisik, mula-mula sebagai madrasah yang dikesankan pinggiran dan tengah sawah, menjadi lembaga yang banyak orang tertarik untuk memandangnya karena arsitekturnya yang bagus serta program inovasinya yang mengundang minat publik, inovasi-inovasinya yang terkesan kreatif, penerapan dan pensikapan terhadap aturan yang cenderung bisa adaptif.

Tujuan Penelitian ini dimaksudkan untuk: (1) menganalisis dan menemukan aspek yang melandasi manajemen pencitraan di MAN Bangil dan MAN Kraton Kabupaten Pasuruan ; (2) menganalisis dan menemukan pola manajemen pencitraan yang dilakukan dalam mewujudkan madrasah berprestasi di MAN Bangil dan MAN Kraton Kab. Pasuruan ; (3) menganalisis dan menemukan bentuk implementasi manajemen pencitraan dalam mewujudkan madrasah berprestasi di MAN Bangil dan MAN Kraton.

Hasil penelitian ini dapat berguna bagi pengembangan pendidikan, baik secara teoritis maupun praktis. Yaitu, pertama adalah Secara substantif penelitian ini dapat menambah khazanah teori dan kontribusi keilmuan tentang manajemen pencitraan madarasah. Dalam penelitian ini dipaparkan tentang konsep dasar manajemen pencitraan, beberapa pola manajemen pencitraan, dan implementasi manajemen pencitraan 
madrasah. Kedua, yaitu diharapkan temuan dalam penelitian ini memberikan kontribusi pemikiran dan informasi yang dapat bermanfaat untuk memajukan madrasah.

Dengan demikian bahwa konsep pengembangan madrasah meninggikan moral, mempertinggi semangat, menghargai nilai-nilai spiritual dan kemanusiaan, mengajarkan sikap dan tingkah laku jujur dan bermoral, serta menyiapkan para murid untuk hidup sederhana dan bersih hati (Maksum, 1977: 41). Hal ini untuk menyongsong kebutuhan masyarakat masa depan agar madrasah yang memiliki kecukupan prasarat secara fisik, representatif, memadai dan menggambarkan sifat-sifat dari kebesaran Islam.

\section{Visi dan misi pendidikan madrasah}

Konfigurasi pengembangan

madrasah berangkat dari akar nilai-nilai filosofis, normatif, religius, serta sejarah panjang perjalanan madrasah di Indonesia. Lingkungan strategis bangsa juga mempengaruhi arah pengembangan madrasah. Dengan terjadinya globalisasi, cita ideal "warga negara" yang baik perlu diperluar menjadi "warga dunia" yang baik sekaligus menjadi hamba dan khalifah Allah SWT yang baik. Pada saat yang bersamaan, perubahan sosial harus diantisipasi agar masyarakat tidak terkooptasi oleh perubahan, tetapi mampu bertindak afirmatif. Misi pendidikan yang melandasi filsafat pendidikan di madrasah adalah rekonstruksi sosial, mengacu kepada ketentuan nilai dan norma keIslaman, dengan menggunakan qaidah almuhafadzah ala al qadim al-shalih wa al akhdu bi al jadid al ashlah.

Kerangka filosofis-normatif yang melandasi pengembangan pendidikan madrasah, diawali dengan asumsi bahwa manusia adalah makhluk Allah SWT yang tercipta dalam bentuk sempurna (ahsan al-taqwim), untuk mengabdi kepada-Nya ('abdullah) dan menjadi wakil/pemimpin (khalifah) di muka bumi. Sebagai 'abdullah, manusia memiliki sikap yang penuh dengan ketundukan dan kepatuhan kepada-Nya. Sedangkan sebagai khalifah, manusia adalah makhluk yang kreatif. Kedua peran ini kemudian digabungkan, maka secara filosofi dapat dirumuskan bahwa pengembangan pendidikan madrasah, harus mampu melahirkan pribadi manusia yang kreatif, dengan landasan sikap ketundukan dan kepatuhan kepada-Nya

Oleh karenanya terkait dengan visi madrasah, merupakan sebuah pandangan atau keyakinan bersama seluruh komponen madrasah akan keadaan masa depan. Keberadaan visi menjadi inspirasi dan mendorong seluruh warga madrasah untuk bekerja lebih giat. Secara fungsional, visi memiliki beberapa fungsi strategis. Pertama, visi diperlukan untuk memobilisasi komitmen, menciptakan energi for action, memberi road map untuk menuju masa depan, menimbulkan antusiasme, memusatkan perhatian dan menanamkan kepercayaan diri. Kedua, visi diperlukan untuk menunjang proses reenginering, restructuring, reinventing, dan bencmarking. Ketiga, visi diperlukan untuk menciptakan dan mengembangkan shared mindsets atau common vision yang menentukan dan menjadi landasan bagaimana seluruh individu mempersiapkan dan berinteraksi dengan stakeholdersnya (Ahmad Zayadi, dkk, 2005: 15).

\section{Tantangan pendidikan madrasah dan manajemen pencitraan}

Madrasah sering kali identik dengan citra buruk dan tidak berkualitas, hal ini disebabkan oleh beberapa hal antara lain pertama, sistem pengelolaan yang didominasi oleh mereka mempertahankan tradisi yang tertutup, yang masih belum menerima perubahan dan enggan melakukan perubahan terhadap lembaga pendidikan. Mereka cenderung memahami Islam sebagai nilainilai agama semata. Kedua, kebanyakan belum memiliki visi, misi dan tujuan yang jelas. Malik Fadjar (1998: 35)menambahkan bahwa dari sekian puluh ribu madrasah yang tersebar di seluruh pelosok tanah air, sebagian besar masih bergumul dengan persoalan berat 
yang sangat menentukan hidup dan mati, sehingga nilai tawar semakin rendah.

Oleh Karena itu membutuhkan media pencitraan agar posisi madarasah dapat dipahami secara utuh karena dua madrasah dalam penelitian ini menunjukkan mutu terdepan di masyarakat. pencitraan merupakan sebagai jenis asosiasi yang muncul dalam benak konsumen ketika mengingat suatu merek atau jasa tertentu. Skema berikut ini adalah proses terbentuknya citra.

Gambar Skema Proses terbentuknya Citra

Secara sistemik terbentukn Opini citra di atas (Nasution, 2006: 25), cit berawal dari persepsi. Persepsi pub menjadisesuatu yang penting untuk dapat menempatkan posisi sebuah produk atau layanan berdasarkan atributnya, karena persepsi di sini merupakan faktor dasar yang mampu mendorong pengguna (stake holder) melakukan pembelian atau penggunaan jasa yang ditawarkan. Persepsi terbentuk dari serangkaian informasi dan atribut yang terkait dengan kebutuhan. Informasi ini bisa bersifat intrinsik yang terkait langsung dengan produk, bisa juga bersifat ekstrinsik yang tidak terkait langsung dengan produk seperti penempatan merek (identitas), biaya, citra, layanan, dan sebagainya. Madrasah yang mempunyai persepsi positif kuat Karena Identitas corporate juga bisa berupa non fisik seperti nilainilai dan filosofi yang dianut institusi, keramahan pelayanan, gaya kerja, dan komunikasi, baik internal maupun dalam interaksi dengan pihak luar. Identitas tersebut memancarkan citra atauimage kepada khalayak atau pihak-pihak terkait (stake holders) antara lain; seperti citra di mata konsumen, masyarakat sekitarnya, investor, dan karyawan sendiri sehingga menjadi citra.

Kesimpulannya pencitraan bukan sekedar membangun persepsi dari dalam dan luar, tetapi ada hubungannya antara pembentukan citra, komunikasi, dan produktifitas, sebagaimana model diagram di bawah ini.

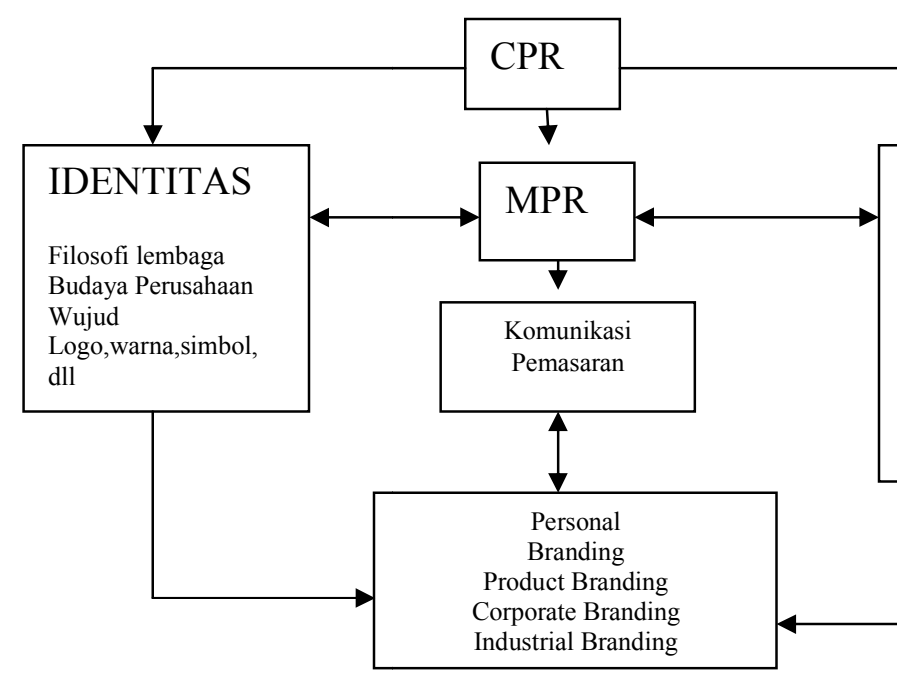

Gambar: Hubungan antara Citra, Komunikasi, dan Marketing (Harris, 1991: 10)

Islam

2. Pencitraan dalam Perspektif

a. Prinsip dan kaidah pencitraan yang terdapat di dalam Al Qur'an adalah sebagai berikut :

1). Dinamis ; yaitu sikap antusiame dalam mengembangkan jaringan kerjasama dan membidik peluang mencakup antara lain:

Membangun simpati dengan performa dan pengaruh baik kepada orang lain:

Al Qur'an surat Az Zumar ayat

23:

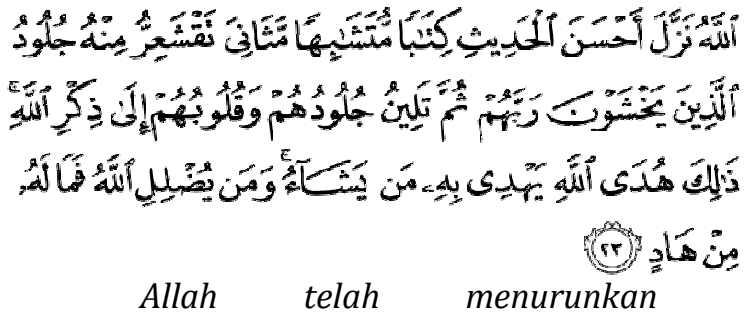

perkataan yang paling baik (yaitu) Al Qur'an yang serupa (ayat-ayatnya) lagi berulang-ulang, gemetar karenanya kulit oreang-orang yang takut kepada Tuhannya, kemudian menjadi tenang kulit dan hati mereka ketika mengingat Allah. Itulah petunjuk Allah, dengan Kitab itu Dia memberi petunjuk kepada siapa yang Dia kehendaki.Dan barangsiapadibiarkan sesat oleh Allah, maka tidak seorangpun yang dapat memberi petunjuk.(QS.Az-Zumar : 23). 
2). Bekerjasama, antara lain :

Di dalam berkompetisi dengan yang lain tetap menunjukkan sikap bersahabat / berkompetisi secara sehat.

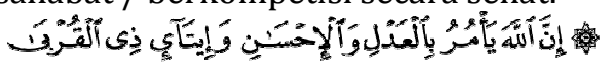

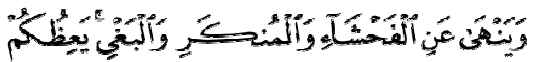<smiles>[Al]C#CC=[W]</smiles>

"Sesungguhnya Allah menyuruh (kamu) berlaku adil dan berbuat $x$ kebajikan, memberi bantuan kepada kerabat, dan Dia melarang (melakukan) perbuatan keji, kemungkaran dan permusuhan. Dia memberi pengajaran kepadamu agar kamu dapat mengambil pelajaran". (QS.An-Nahl : 90)

3). Menjunjung tinggi integritas dan kejujuran, tidak membohongi publik.

Firman Allah surat Al Hujurat ayat 15:

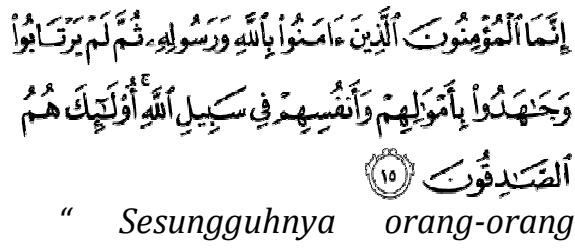

mukmin yang sebenarnya adalah mereka yang beriman kepada Allah dan RasulNya, kemudian mereka tidak ragu-ragu, dan mereka berjihad dengan harta dan jiwanya di jalan Allah. Mereka itulah orng-orang yang benar".(QS.Al Hujurat ayat 15)

4). Menggunakan pendekatan komunikasi yang tepat, antara lainmenggunakan bahasa/perkataan yang benar

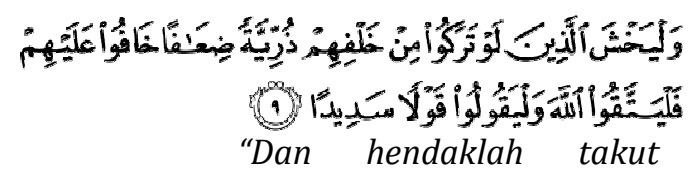

kepada Allah orang-orang yang seandainya meninggalkan di belakang mereka anakanak yang lemah, yang mereka khawatir terhadap (kesejahteraan) mereka. Oleh sebab itu hendaklah mereka bertaqwa kepada Allah dan hendaklah mereka mengucapkan perkataan yang benar " (QS.An Nisa : 9)

perspektif al- Hadits ;
Mengedepankan aspek kebersamaan, bermusyawarah, prinsip kolektif kolegial.

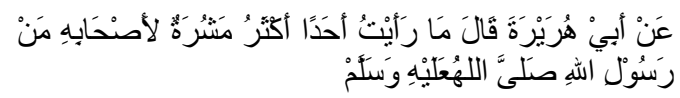

Dari Abu Hurairah berkata, Aku tidak menemukan orang yang lebih banyak bermusyawarah selain Rasulullah SAW. (H.R At-Tirmizi).

\section{Manajemen Pencitraan untuk Mewujudkan Madrasah yang Berprestasi.}

Madrasah dapat mewujudkan prestasi salah satunya karena ditopang dengan pola manajemen yang luwes dan fleksibel. Strategi pengelolaan pendidikan yang mengedepankan azas kerjasama antara berbagai pihak dan penerjemahan terhadap aturan baku, lebih dikenal dengan istilah the collaborative school management (B.Suryobroto, 2004: 195).

Dalam teori manajemen, pembangunan citra merupakan salah satu bagian yang tidak terpisahkan dari strategi marketing. Arthur W. Page (1999: 82) dalam Sagara menjelaskan bahwa strategi pencitraan adalah sebuah upaya yang tidak datang tiba-tiba dan tidak bisa direkayasa. Citra akan datang dengan sendirinya dari upaya yang ditempuh sehingga komunikasi dan keterbukaan perusahaan atau institusi merupakan salah satu faktor utama untuk mendapatkan citra yang positif.Hal ini memerlukan waktu yang panjang dan selalu belajar dari pengalamanpengalaman dalam melayani pengguna produk atau jasa. Hal ini sebagaimana pernyataan Michell yang menegaskan bahwa esensi pencitraan bagi institusi adalah dalam rangka repositioning dan merebut pangsa pasar (Jhonatan E.,2009: 7). Karakter brand supaya menjadi berpotensi harus memperhatikan sebagai berikut; 1). A quality product (sejak kepuasan konsumen digunakan untuk mengukur nilai-nilai merek (brand values), kualitas adalah nomor satu yang diinginkan konsumen.2).Being 
first(menjadi yang pertama dalam pasar, bukan dalam teknologi). 3). Unique positioningconcept (merek harus memiliki posisi konsep yang unik, yang akan membedakan dari kompetitornya). 4). Strong communications program (merek yang sukses harus disertai dengan penjualan yang efektif, pengiklanan, kampanye, promosi yang akan mengkomunikasikan fungsi dari brand itu dan nilai-nilai yang terkandung di dalamnya.

Pola pencitraan yang dilakukan pada sisi manajemen adalah bagaimana madrasah secara kelembagaan memiliki kemampuan untuk memunculkan prakarsa dan kemampuan-kemampuan kreatif di dalam mengidentifikasi peluang dan potensi yang dimiliki, menerjemahkannya dalam rancangan program, merealisasikan dalam bentukbentuk kegiatan, mengacu pada pola-pola tertentu, dengan tetap berada dalam bingkai visi, misi, dan tujuan kelembagaan madrasah. Di samping itu juga ditandai dengan berkembangnya organisasi madrasah yang lebih berorientasi profesionalisme, menghindari kultur tradisional yang cenderung berbasis otoritatif, kharismatik, dan tersentral pada pihak tertentu.

Komunikator pemasaran harus memiliki target pendengar yang jelas. Pendengar (audience) dapat terdiri dari calon pembeli potensial dari produk perusahaan, pemakai produk, pengambil keputusan atau pemberi pengaruh. Dalam konteks madrasah, dibutuhkan pemahaman tentang input-input potensial, kantong-kantong masyarakat yang secara kultur dan fanatis menjadi pelanggan madrasah, pengguna layanan madrasah, pihak-pihak yang dapat mempengaruhi opini masyarakat. Audience tersebut bisa terdiri dari individu, kelompok, atau masyarakat khusus dan umum. Target audience ini akan berpengaruh terhadap keputusan yang diambil komunikator tentang apa, bagaimana, kapan, dimana dan kepada siapa harus bicara.Komunikator harus mengetahui pula karakteristik dari audiencenya. Dengan melakukan audience analysis yang dikenal dengan image analysis, yaitu menilai image audience saat ini mengenai perusahaan, dalam konteks penelitian ini terhadap madrasah tentang program-programnya dan pesaingpesaingnya.

Sebagaimana dalam pembahasan sebelumnya, pada ayat-ayat $\mathrm{Al}$ Qur'an sarat akan nilai-nilai yang mengisyaratkan akan pentingnya menyampaikan pesan secara bijak, bahasa yang arif, memuliakan, tidak membohongi atau sekedar kamuflase, ditampilkan secara menarik, dan mengindikasikan akan kemanfaatan yang didapatkan. Integrasi antara pola pendekatan marketing dengan semangat yang ada di dalam al Qur'an, menurut hemat peneliti menjadi sebuah formulasi penting untuk memberikan kontribusi terhadap khazanah pemikiran pendidikan dan praktisi madrasah.

Madrasah berprestasi merupakan istilah yang kurang lebih memiliki "persamaan" dari exellence school, good school, effective school, improvementschool dan berbagai istilah yang biasanya digunakan untuk menunjukkan kualitas madrasah biasa dengan madrasah yang unggul (Freymer dkk, 1984: 112). Karakteristik madrasah berprestasi dapat dilihat dari sisi in-put proses dan outputnya. Hal ini sebagaimana yang diungkapkan oleh Muhaimin $(2008,104-105)$ terlihat dalam tabel berikut: 
Tabel Karakteristik Madrasah Berprestasi

\begin{tabular}{|c|c|}
\hline ASPEK & KARAKTERISTIK \\
\hline Input & $\begin{array}{l}\text { 1. Memiliki kebijakan, tujuan dan sasaran mutu yang jelas; } \\
\text { 2. Adanya sumber daya yang tersedia dan siap } \\
\text { 3. Staf yang kompeten dan berdedikasi tinggi; } \\
\text { 4. Memiliki harapan prestasi yang tinggi } \\
\text { 5. Fokus pada pelanggan (khususnya siswa); } \\
\text { 6. Adanya input manajemen, yang ditandai dengan tugas yang jelas, } \\
\text { rencana rinci dan sistematis, program yang mendukung pelaksanaan } \\
\text { rencana dan sistem pengendali mutu yang fektif. }\end{array}$ \\
\hline Proses & $\begin{array}{l}\text { 1. Proses pembelajaran efektif; } \\
\text { 2. Kepemimpinan madrasah yang kuat; } \\
\text { 3. Lingkungan madrasah yang aman dan tertib; } \\
\text { 4. Pengelolaan tenaga kependidikan yang efektif; } \\
\text { 5. Memiliki budaya mutu; } \\
\text { 6. Memilikin team work kompak, cerdas, dan dinamis; } \\
\text { 7. Memiliki kemandirian; } \\
\text { 8. Adanya partisipasi yang tinggi dari masyarakat; } \\
\text { 9. Mempunyai keterbukaan; } \\
\text { 10. Mempunyai kemauan untuk berubah baik psikologis maupun fisik; } \\
\text { 11. Melakukan evaluasi dan perbaikan secara berkelanjutan; } \\
\text { 12. Responsive dan antisipatif terhadap kebutuhan; } \\
\text { 13. Memiliki komunikasi yang baik; } \\
\text { 14. Mempunyai akuntabilitas; } \\
\text { 15. Memiliki dan menjaga sustainabilitas dalam program dan pendanaan. }\end{array}$ \\
\hline Out put & $\begin{array}{l}\text { 1. Prestasi akademik ditunjukkan dengan NUN, lomba karya ilmiah, } \\
\text { lomba mata pelajaran, cara berfikir. } \\
\text { 2. Prestasi non akademik ditujukan dengan keingintahuan yang tinggi, } \\
\text { kerjasama yang baik, rasa kasih sayang yang tinggi terhadap sesama, } \\
\text { toleransi, kedisiplinan, kerajinan, prestasi olahraga dan kesenian, } \\
\text { kepramukaan, dll. }\end{array}$ \\
\hline
\end{tabular}

Substansi dari prestasi adalah akumulasi hasil dari sebuah proses yang dilakukan secara terencana, disengaja, terprogram, terukur, dan dalam jangka waktu tertentu. Prestasi tidak muncul secara tiba-tiba, tetapi melalui tahapan yang terorganisir secara baik.

Keberhasilan madrasah dalam membangun pencitraan diri sebagai yang berprestasi bila memiliki rencana dan kegiatan nyata untuk menentukan posisinya di masyarakat serta berhasil membidik segmentasi tertentu sesuai dengan tujuan yang telah ditargetkan. Bagaimana madrasah membuat rencana dan menelorkan ide serta melaksanakannya dengan melibatkan pihak yang berkompeten, serta menggunakan model yang didasarkan atas analisa kebutuhan masyarakat, dan memiliki skala prioritas atau target sasaran tertentu .

Berdasarkan beberapa teori dan konsep di atas, dihasilkan suatu kerangka berfikir mengenai manajemen pencitraan mewujudkan madrasah berprestasi, dapat digambarkan dalam kerangka berfikir sebagai berikut. 


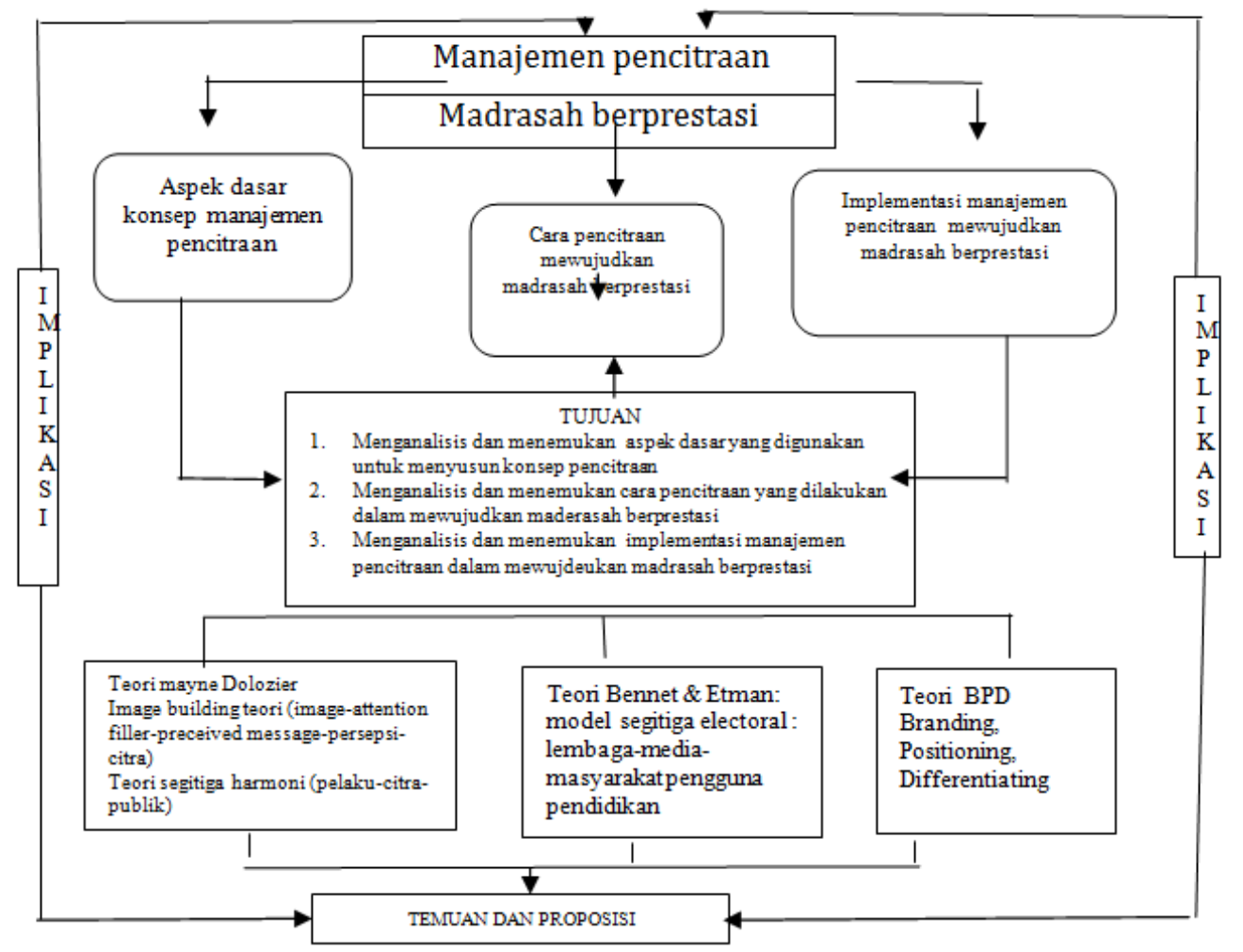

Manajemen pencitraan mewujudkan madrasah berprestasi dijabarkan melalui tiga focus penelitian, yaitu : aspek dasar yang dijadikan landasasn dalam menyusun konsep manajemen pencitraan, model manajemen pencitraan dalaqm mewujdukan madrasah berprestasi, dan implementasi manajemen pencitraan dalam mewujdukan madrasah berprestasi. Tujuannya adalah : menganalisis dan menemukan aspek dasar apa yang digunakan untuk menyusun program manajemen pencitraan di MAN bangil dan MAN Kraton, menganailsais dan menemukan model manajemen pencitraan dalam mewujdukan madrasah berprestasi di MAN Bangil dan MAN Kraton, serta menganalisa dan menemukan bentuk implementasi manajemen pencitrraan dalam mewujudkan madarasah yang berprestasi.

\section{Pendekatan dan rancangan penelitian}

Penelitian ini bersifat naturalistic, dengan pendekatan interpretivisme. Metode yang digunakan adalah pendekatan kualitatif deskriptif. (Lexy J. Moeleong, 2004: 41).Sementara itu pengertian deskriptif adalah yang melukiskan suatu obyek atau peristiwa historis tertentu yang kemudian diiringi dengan upaya pengambilan kesimpulan umum berdasarkan fakta-fakta historis tertentu (Hadari Muhammad, 2002: 26). Adapun Rancangan penelitian ini bersifat multisitus, maksudnya adalah suatu kasus yang sama dalam suatu penelitian, tetapi lokasi penelitian yang berbeda namun memiliki persamaan.Situs yang digunakan dalam penelitian ini adalah MAN Bangil dan MAN Kraton.

\section{Data dan Sumber Data}

1. Data

Informan penelitian ditetapkan dengan menggunakan teknik snowballsampling (Bodgan dan Biklen,1998,'102). Adapun yang menjadi informan dalam penelitian ini adalah (a) subyek yang cukup lama dan intensif menyatu dengan suatu kegiatan (b) subyek yang masih terlibat secara aktif di lingkungan (c) subyek yang bersifat lugu dalam memberikan informasi, dan 
(d) subyek yang mempunyai cukup banyak waktu.

2. Sumber data

Sumber data dalam penelitian ini dibedakan menjadi dua yaitu manusia dan bukan manusia.Sumber.

\section{Prosedur Pengumpulan Data}

Adapun metode yang dipergunakan adalah metode observasi, interview, dan dokumentasi, atau menggunakan tiga teknik yang ditawarkan oleh Bodgan dan Biklen(1986, 119-143), yaitu 1) observasi partisipan (participantobservation); 2) wawancara mendalam (indepth interview); dan 3) studi dokumentasi (study document). John W.Creswell menambah, yaitu:Audiovisual materials (1994, 148-150)), sedangkan Robert K.Yin (1987: 79) menyarankan enam teknik, yaitu : 1) dokumen (documentation);2) rekamanarsip (archival record);3) wawancara (interview); 4) observasi langsung (direct observation); 5) observasi partisipan (participantobservation); 6) perangkat fisik (physical artifact).

Hal-hal yang diamati dalam penelitian ini, agar mudah dipahami, disajikan dan dirinci pada tabel berikut ini:

Tabel Ragam Situasi yang Diobservasi

\begin{tabular}{|c|c|c|}
\hline No & $\begin{array}{c}\text { Ragam } \\
\text { Situasi } \\
\text { yang } \\
\text { Diamati }\end{array}$ & Keterangan \\
\hline 1. & $\begin{array}{l}\text { Visi misi } \\
\text { dan } \\
\text { budaya } \\
\text { madrasah }\end{array}$ & $\begin{array}{l}\text { a. penyusuran } \\
\text { tentang visi dan } \\
\text { misi madrasah : apa } \\
\text { yang menjadi } \\
\text { impian atau obsesi } \\
\text { dari warga } \\
\text { madrasah, } \\
\text { bagaimana cara } \\
\text { menerjemahkan } \\
\text { visi misi tersebut } \\
\text { dalam program. } \\
\text { b. Penyusuran } \\
\text { tentang ragam } \\
\text { budaya yang } \\
\text { dikembangkan }\end{array}$ \\
\hline
\end{tabular}

\begin{tabular}{|c|c|c|}
\hline & & $\begin{array}{l}\text { madrasah baik } \\
\text { dalam tataran } \\
\text { akademik, kultur } \\
\text { religious, dan } \\
\text { pembiasaan }\end{array}$ \\
\hline 2. & $\begin{array}{l}\text { Model } \\
\text { pencitraan }\end{array}$ & $\begin{array}{l}\text { Pengamatan } \\
\text { mengenai: } \\
\text { a. Kegiatan yang } \\
\text { menjadi kekhasan } \\
\text { madrasah } \\
\text { b. Program - } \\
\text { program yang } \\
\text { bertujuan untuk } \\
\text { meningkatkan } \\
\text { prestasi } \\
\text { c. Upaya-upaya } \\
\text { membangun } \\
\text { kepercayaan } \\
\text { public } \\
\text { d. Piranti, media, } \\
\text { struktur bahasa, } \\
\text { yang digunakan } \\
\text { untuk } \\
\text { mengkomunikasi- } \\
\text { kan } \\
\text { program/kegiatan } \\
\text { kepada publik. }\end{array}$ \\
\hline 3. & $\begin{array}{l}\text { Prestasi- } \\
\text { prestasi } \\
\text { yang } \\
\text { dicapai } \\
\text { sebagai } \\
\text { dampak } \\
\text { dari } \\
\text { pencitraan } \\
\text { yang } \\
\text { dilakukan }\end{array}$ & $\begin{array}{l}\text { Observasi } \\
\text { mengenai hasil } \\
\text { yang dicapai } \\
\text { madrasah }\end{array}$ \\
\hline
\end{tabular}

\section{Pembahasan Hasil Penelitian}

Pada bagian ini memuat tiga hal yang akan diuraikan secara berurutan mengenai : (1) konsep dasar manajemen pencitraan mewujudkan madrasah yang berprestasi ; (2) pola pencitraan madrasah yang berprestasi; (3) implementasi manajemen pencitraan mewujudkan madrasah yang berprestasi;

$\begin{array}{crr}\begin{array}{c}\text { Aspek } \\ \text { penyusunan }\end{array} & \begin{array}{r}\text { yang } \\ \text { program }\end{array} & \begin{array}{r}\text { mendasari } \\ \text { manajemen }\end{array}\end{array}$


pencitraan mewujdukan madrasah yang berprestasi.

Aspek dasar di dalam penyusuan program manajemen pencitraan dalam mewujudkan madrasah yang berprestasi setidaknya berangkat dari pandangan Philip Kotler dan Lan Keller (2009: cet 4) tentang peran marketing dalam institusi modern. Terdapat beberapa aspek alam konteks keterserapannya pada pasar. Pertama, memberikan pemahaman obyektif terhadap relitas konsumen yang sudah familiar dengan globalisasi informasi, sebagai keniscayaan global. Kedua, perlunya melakukan evaluasi terhadap efektivitas produk,d an ketiga, program yang disukai konsumen dan berdampak baik bagi masyarakat.

Berdasarkan visi dan misi lembaga sebagaimana yang menjadi citacita kedua madrasah secara substansial ingin mewujudkan madrasah yang merepresentasikan harapan publik dan semangat kompetiitif yang seharusnya dimiliki oleh lembaga untuk mampu berkompetitsi di dalam suasana liberalisasi pendidikan dewasa ini. Kedua madrasah sama-sama mengusung visi berkualitas, unggul, dan kompetitif..

Prinsip-prinsip perencanaan juga dilakukan oleh kedua madarasah berdasarkan pada jangka waktu yaitu jangka pendek, menengah, dan panjang. Model perencanaan ini seperti yang diungkapkan oleh Gibson bahwa perencanaan meliputi; (1) perencanaan jangka pendek dengan waktu satu minggu, bulan dan tahun, (2) perencanaan jangka menengah dalam jangka waktu 2 sampai 5tahun, dan (3) perencanan jangka panjang yang dibuat lebih dari 5 tahun.

Untuk mencapai sasaran dan tujuan yang ingin dicapai oleh lembaga pendidikan dan dalam uapaya manajemen pencitraan sebagai aspek kedua, MAN Bangil dan MAN Kraton sama-sama melakukan pembacaan terhadap perubahan yang terjadi di dunia global dengan melakukan analisa internal dan eksternal meliputi : (1) kekuatan dan kelemahan internal (internal strenghts and wearknes) (2) peluang dan ancaman eksternal (external opportunities and threats) yang dihadapi oleh madrasah di masa yang akan datang. Analisa internal kedua madrasah dilakukan yaitu dengan mengidentifikasi perbedaan dan keunikan diri yang dipunyai tanpa berupaya mengada-ada atau membuat-buat agar terkesan seolah - olah,.

Model analisis seperti ini sebagaimana methode diagram sebab akibat. Metode ini dipakai dalam perencanaan yang menggunakan sekuen hipotetik untuk mendapatkan gambaran masa depan yang lebih baik.Metode analisis yang digunakan memiliki kesamaan dengan pendekatan strategik yang dikemukakan oleh David Fred R (2005: 13-15) yaitu ; Pertama, melakukan analisis SWOT (Strenght,Wearknes, Opportunity and Treat). Kedua, melakukan analisis tindakan atau langkah-langkah yang tepat, yang dapat dilaksanakan dalam menghadapi beragam tantangan atau problem yang muncul pada masa yang akan dating. Hal ini seseuai dengan firman Allah yang dijelaskan dalam $\mathrm{Al}$ Qur'an :

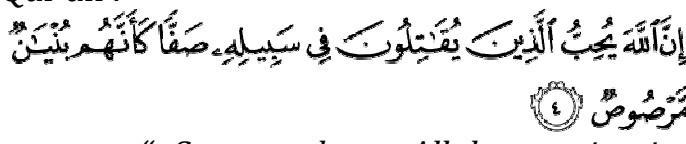

"Sesungguhnya Allah mencintai orang-orang yang berperang di jalan-Nya dalam barisan yang teratur, mereka seakan-akan seperti suatu bangunan yang tersusun kokoh".(QS.As-Saff: 4)

Makna yang terkandung dalam ayat di atas memberikan gambaran bahwa segala sesuatu hendaknya dilakukan dengan terorganisir secara baik.Ayat di atas memberikan inspirasi bahwa sebuah rencana program akan dapat terlaksana dengan baik bila didukung oleh seluruh komponen secara solid. Di dalam kedua madrasah terdapat struktur organisasi yang di dalamnya ada divisi hubungan masyarakat (humas). Hasil penelitian membuktikan bahwa MAN Bangil semakin diminati dengan input yang bersumber dari berbagai wilayah, dengan latarbelakang lembaga yang variatif. Ada dari MTs negeri ataupun swasta, dan dari SMP negeri atau swasta, sebuah fenomena menarik bahwa beberapa sekolah, para 
siswanya menjadi siswa MTs yang secara tradisi dari tahun ke tahun memberikan kontribusi basar terhadap banyaknya jumlah pendaftar.

Akan halnya MAN Kraton, konsentrasi untuk merubah cara berfikir masyarakat adalah dalam rangka meyakinkan publik terhadap eksistensi MAN Kraton sebagai lembaga pendidikan yang sebenarnya statusnya terpisah dengan pesantren Al Yasini. Penegasan terhadap status melalui penamaan yang tidak lagi diikuti embel-embel Al Yasini merupakan langkah yang berani untuk setidaknya keluar dari zona sejarah yang mana publik sudah terlanjur memafhuminya sebagai bagian yang tidak terpisah dari pesantren. Beberapa program yang digulirkan seperti pengembangan bahasa Inggris, olympiade mata pelajaran, dibukanya kelas unggulan prestasi, adalah upaya-upaya untuk menegaskan "brand" MAN Kraton sebagai lembaga negeri yang bukan Al Yasini.

\section{Pola manajemen pencitraan untuk mewujudkan madrasah yang berprestasi.}

Pola yang dikembangkan dalam manajemen pncitraan madrasah di kedua madrasah berorientasi pada tiga pendekatan dalam teori pemasaran yaitu branding (merek), positioning (posisi), dan differentiating (perbedaan). Branding memuat filosofi untuk menjadi yang superior (yang paling), dengan menganut prinsip ketunggalan (singularity). Sementara differentiating ( berbeda) adalah mensikapi sifat dasar manusia yang cenderung tertarik pada sesuatu yang berbeda dan tidak biasa. Ketika muncul produk yang sama sekali belum ada sebelumnya cenderung public merasa ingin tahu dan cenderung memusat perhatiannya. Di samping kedua unsur, segmentation (menentukan pangsa pasar), dilandasi oleh konsep bahwa kenyataannya konsumen berbeda-beda, maka diperlukan program-program yang berbeda-beda pula. Memperkuat konsep tersebut, ketika diterapkan dalam dunia madrasah sangat sesuai dengan inspirasi yang tersirat di dalam $\mathrm{Al}$ Qur'an surat $\mathrm{Al}$ Hujurat ayat 15:

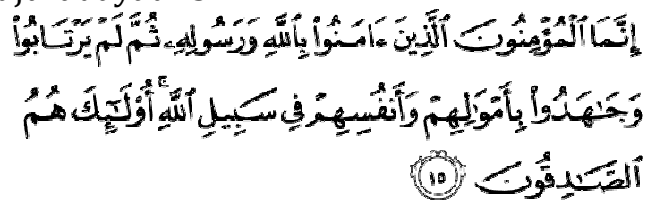

"Sesungguhnya orang-orang mukmin yang sebenarnya adalah mereka yang beriman kepada Allah dan RasulNya, kemudian mereka tidak ragu-ragu, dan mereka berjihad dengan harta dan jiwanya di jalan Allah. Mereka itulah orng-orang yang benar".(QS.Al Hujurat ayat 15)

Ayat di atas memberikan spirit akan perlunya mengedepankan integritas dan kejujuran di dalam mempublikasikan apa yang dilakukan oleh madrasah. Pencitraan dipandang berhasil ketika memenuhi beberapa parameter penting diantaranya; (1) meningkatnya kepuasan pelanggan; (2) banyaknya peserta didik yang antusias dan berminat ingin belajar di lembaga tersebut; (3) banyaknya lembaga lain khususnya yang berada di level atas yang menawarkan kerjasama dalam berbagai hal.

Ketiga unsur dalam komunikasi sebagaimana digambarkan di atas memiliki fungsi dan peran ideal masingmasing sebagaimana terlihat dari arah hubungan satu sama lain. Masyarakat pendidikan (masyarakat, orangtua siswa) mendapatkan informasi perihal profil, program, prestasi, dari media yang bertindak sebagai penyedia jasa yang memberikan informasi sekaligus berpihak kepada kepentingan publik.

Dari pembahasan ini di atas, dapat dirumuskan temuan konseptual mengenai manajemen pencitraan mewujudkan madrasah yang berprestasi, sebagaimana gambar model manajemen pencitraan mewujdukan madrasah yang berprestasi skema berikut ini : 


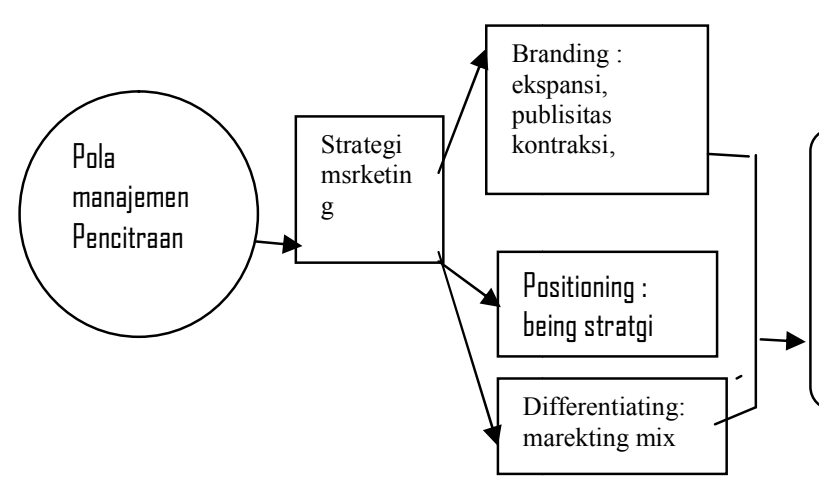

\section{Implementasi manajemen pencitraan mewujudkan madrasah yang berprestasi.}

Implementasi di lapangan masingmasing memiliki jenis program yang tidak sama satu sama lainnya. Program yang diandalkan di MAN bangil adalah PRODISTIK (kerjasama ITC dengan ITS), sementara MAN Kraton mengandalkan program olympiade sains dan keagamaan. Nemun demikian dalam hal pandangan tentang perlunya dikomunikasikan kepada pihak eksternal dan masyarakat luas, kedua lembaga menganggap sebagai sebuah keharusan dan sangat besar efeknya bagi terbangunnya persepsi public.

MAN Bangil dan MAN Kraton menegaskan bahwa program untuk mengkomunikasikan kegiatan dan prestasi merupakan program berkelanjutan dan dilakukan secara terus menerus.Sarana media yang ada dimanfaatkan secara maksimal, bahkan komitmen untuk bekerjasama dengan media massa masuk dalam rencana program dan didukung dengan

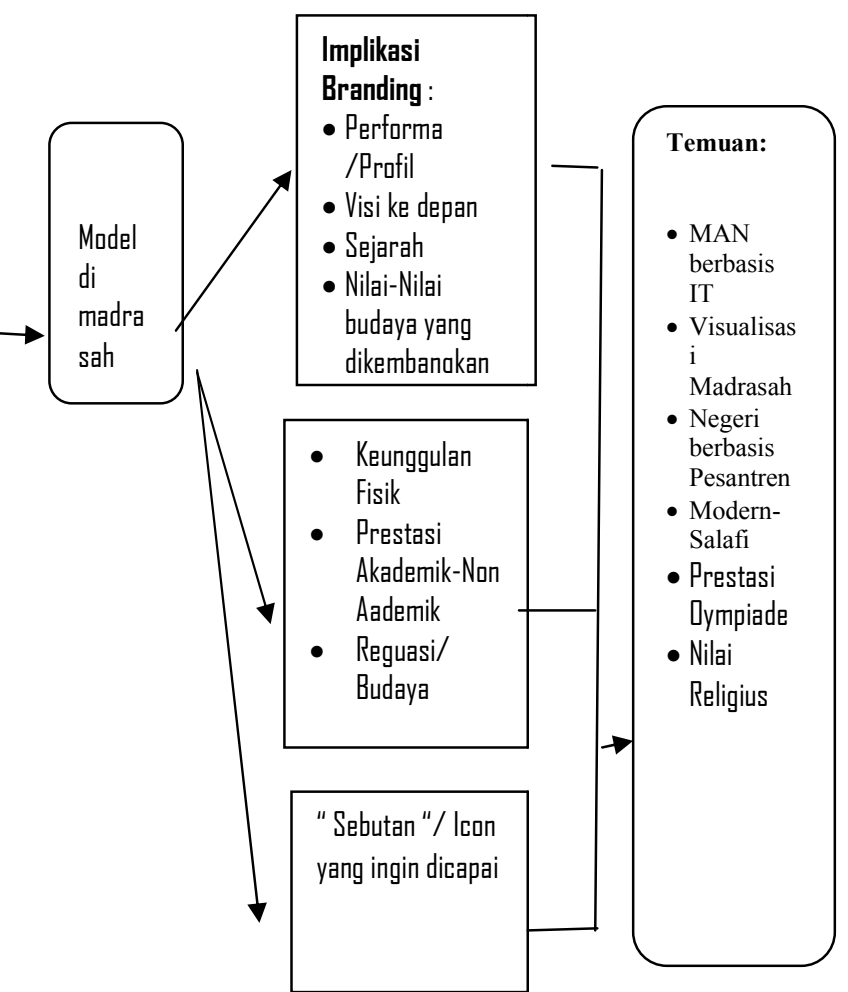

pembiayaan yang dari tahun ke tahun terus meningkat.

Kedua MAN memenuhi prasarat sebagai institusi yang melakukan pola pengelolaan berbasis mutu karena memiliki kecenderungan para civitas madrasahnya berkehendak agar terjadi perubahan strukutur dan kultur organisasinya. MAN Bangil menekankan pendekatan delegatif dimana tugas dan wewenang masing-masing bidang diberikan keleluasaan untuk melakukan tugas sekaligus melakukan inovasi secara longgar. Sementara, MAN Kraton, atmosfir organisasinya menginginkan kuat agar benar-benar lepas dari bayang-bayang Yayasan. Pola paternalistik sebagaimana karakteristik pola manajemen yayasan berubah ke arah partisipatif dan kolegial. Sebagaimana pesan Al Qur'an :

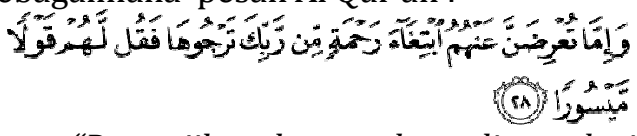

"Dan jika kamu berpaling dari mereka untuk memperoleh rahmat dari tuhanmu yang kamu harapkan, maka katakanlah kepada mereka ucapan yang pantas". (QS.Al Isra' : 28). 
Pencitraan dilakukan dengan cara mengkomunikasikan secara intensif segala aktifitas dan capaian prestasi yang dilakukan, kesediaan untuk didatangi oleh media dan pihak yang berkepentingan untuk meliput dan mendapatkan informasi seputar lembagaPembahasan terhadap temuan penelitian dapat dirumuskan temuan konseptual mengenai manajemen pencitraan mewujudkan madrasah berprestasi, sebagaimana skema berikut ini:

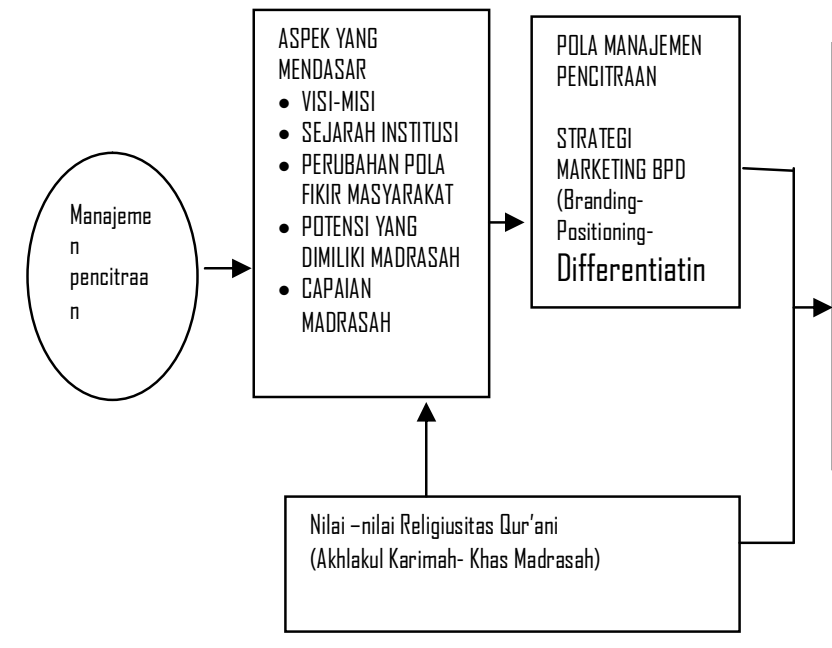

\section{Kesimpulan}

Berdasarkan fokus penelitian, paparan data dan temuan kasus individu serta pembahasan, hasil penelitian ini disimpulkan sebagai berikut :

1. Madrasah menentukan pola manajemen pencitraan berkesesuaian dengan teori BPD sebagaimana strategi marketing di dunia usaha, yaitu melalui penguatan merek (brand), meraih pangsa pasar (position), dan mengedepankan keunikan / kekhasan (differentiation) sebagai sebuah keniscayaan untuk menghadapi kompetisi dan tuntutan dalam memberikan pelayanan yang optimal kepada masyarakat. Di samping itu juga, penguatan struktur, memunculkan program yang unik menarik, menjalin hubungan lintas sektoral secara luas, mengadopsi manajemen entrepreneurship, serta pemanfaat media merupakan upaya menjawab trend pasar.

2. Sesungguhnya madrasah memiliki kekhasan sekaligus karakter khas yaitu etika religious yang bersumber dari Al Qur'an dan Hadits Nabi. Tanpa dicitrakanpun madrasah memiliki potensi untuk diminati. Penerapan teori BPD (branding, positioning, dan differentiating) adalah dalam rangka meningkatkan mutu

madrasah ketika realitas menunjukkan bahwa madrasah sebagai bagian dari entitas lembaga pendidikan tidak bias steril dari komoditas.

3. Kontribusi dari temuan ini adalah dalam rangka mengembangkan kerangka teori BPD dengan menambahkan etikla religious sebagai solusi efektif yang dapat diberlakukan di madrasah.

\section{Daftar Pustaka}
Alma,Buchari , 1992 , Manajemen Pemasaran dan Pemasaran Jasa, Bandung : Alfabeta.

Al -Alusi, Shihab Al -Din, 2005, Tafsir Ruh Al-Ma'ani, juz 3 (Maqiu at tafsir: dalam Sofware al-Maktabah al Syamilah.

Al Ries, Laura Ries, (Hermawan Kertajaya,terj), 2000, The 22 Immutable Laws of Branding 
(Strategi Membangun Produk atau Jasa Menjadi Merek Berkelas Dunia),Jakarta: PT. Gramedia Pustaka Utama berekerjasama dengan MarkPlus Publication

A.Fatih Syuhud, 2005, Tantangan Pendidikan Islam di Era Globalisasi, PPI- India : Journal VISI, Posted 6 September 2005.

Anggara, Linggar, 2002, Teori dan Profesi Kehumasan, Serta Aplikasinya di Indonesia,Cetakan ke-tiga Jakarta : Bumi Aksara.

Asmani, Jamal Ma'mur,2015, Manajemen Efektif Marketing Sekolah, Yogyakarta: DIVA Press.

Ardianto,Elvinaro dan Sumirat, Saleh , 2004, Dasar-dasar Public Relation, Cetakan ketiga, Bandung: Remaja Rosdakarya.

Arikunto, Suharsimi, 2002, Pengantar Penelitian Kualitatif ,Surabaya : Usaha Nasional.

Arthur, W. Page, 2009, All Business in a Democratic Country begins with Public Permission and Exist byPublic Approvala, dalam Edo Sagara, Journal .

B.Aubrey Fisher, 1990, Teori-Teori Komunikasi (penyunting: Jalaluddin Rakhmat), Bandung : PT. Remaja Rosdakarya.

Bodgan and Biklen, Robert C. Dan Sari Knop Biklen, 1990, Riset Kualitatif untuk Pendidikan : Pengantar ke Teori dan Metode, Munandir (terj), Jakarta : Dirjend Perguruan Tinggi, Depdikbud .

Cantor,Bill, 1984:438 dalam Sanaky, 2006, Peran Public Relation dalam Kompetisi Dunia Usaha, Jogjakarta: Rake Sarasin.

Chotimah, Chusnul, 2013, Manajemen Public Relations Integratif, Konsep teori, dan Aplikasinya di Pesantren Tradisional, STAIN Tulungagung Press.
Creswell, John, W.2009, Research Desain Pendekatan Kualitatif, Kuantitatif, dan Mixed. Terj. Achmad fawaid, Jogjakarta: Pustaka Pelajar.

Dananjaya, 2011, Peranan Humas dalam Perusahaan, Surabaya : Graha Ilmu.

Depari, Eduard, 1997, Public Relations dan Pengembangan Citra Perusahaan, Makalah dalam Seminar Kehumasan, Prospek dan Tantangan PR dalam Menyongsong Era Perdagangan Bebas, Surabaya : IAIN Press, 22 Nov 1997.

Eliyasin, Muhammad \& Nurhayati, Nanik, 2012, Manajemen Pendidikan Islam, Yogyakarta : Aditya Media Publishing

Fadjar,Malik.A, 2000, Madrasah dan Tantangan Modernitas, Jakarta : Mizan

Faisal, Sanapiah, 2003, Format-Format Penelitian Sosial, Jakarta : Raja Grafindo Persada.

Frazier,Moore,H, 2004, Humas, Membangun Citra dengan Komunikasi, Bandung : PT Rosdakarya Remaja

Fuad Abdul Baqi', Muhammad, 2006, Al Lu'lul' wal Marjan (Himpunan Hadits Shahih yang Disepakati oleh Imam Bukhori dan Muslim), Surabaya : PT.Bina Ilmu.

Greener, Toni, 2002, Public Relations dan Pembentukan Citranya, Cetakan ketiga, Jakarta : Bumi Aksara.

Hadari Muhammad ,2002, Metodologi Penelitian,Sebuah Analisa Kwalitatif, Yogyakarta : Rake Sarasin.

Hadi, Amirul dan Haryono,1998, Metodologi Penelitian Pendidikan, Bandung : Pustaka Setia.

Haidar Putra, Daulay,2010,Historisitas dan Eksistensi Pesantren, Sekolah dan Madrasah, Yogyakarta : Tiara Wacana.

Irianto, Yosal, 2004, Community Relations, Konsep dan 
Aplikasinya,Bandung : Simbiasa Rekatama Media.

Ismail, 2010, Management Pencitraaan dalam Sistem Manajemen Mutu Terpadu pada Madrasah Unggulan Nasional ( Studi di MAN Insan Cendekia Serpong), Semarang : Lemlit IAIN Walisongo.

Jefkins, Frank, 2009, Public Relations, edisi ke-5 (Revisi oleh: Daniel Yadin, Surabaya: Penerbit Erlangga.

Jhonatan .E , 2009, Branding dalam Teori Marketing, Jakarta : Grafiti Press

Kasali, Rhenald, 2000, Manajemen Humas, cetakan VII, Jakarta : Grafiti Press.

Kasali, Rhenald, 1999, Membidik Pasar Indonesia, Segmentasi Targting Positioning, Jakarta : PT. Gramedia Pustaka Utama.

Kertajaya, Hermawan, 1994, The Strategic Marketing Plus 2000 Contripugal Framework for Competitive Audit, Strategy-Formulation \& Capability Enhanchement, Jakarta : Majalah SWA, IV.

Kotler, Philip \& Gary Amstrong, 2006, Principles of Marketing, Elevanth Edition, New Jersey : Pearson Prentice Hall.

Kriyantono,Rahmad, 2008, Public Relations Writing: Membangun Public Relations Membangun CitraCorporate, Jakarta:Kencana.

Langgulung, Hasan, 1980, Beberapa Pemikiran tentang Pendidikan Islam, Bandung: Al Ma'arif.

Lina Sinatra dan Rini Darmastuti,2008, Kajian Peran PR dalam Meningkatkan Citra PT.Swasta di Jateng, UGM Press: Jurnal Ilmiah SCRIPTURA, Vol.2 No.2 .

Mantja, W., 2003, Etnografi Desain Penelitian Kualitatif dan Manajemen Pendidikan, Malang : Winaka Media.

Martinez,Eva \& Jose M.Pina , 2003, The Negative Impact of Brand Extensions onParent Brand Image,
Journal of Product \& Brand Management, Vol.12 , No.7.

Maureen Fiz Gerald and David Arrotf, 2000, Merketing Communication Clasic, New Jersey : Prentice Hall

Maksum, 1999, Madrasah Sejarah dan Perkembangannya, Ciputat : PT .Logas Wacana Ilmu.

Marzuki, C. Sahril, 1997, Profil Sekolah Berkesan di Malaysia, Berdasarkan Model Lima Faktor, Journal Pendidikan (Journal of Education Research, jilid 18).

Mastuhu, 1999, Memberdayakan Sistem Pendidikan Islam, Ciputat : PT Logos Wacana Ilmu.

Mas'ud Abdurrahim,2002, Dinamika Pesantren dan Madrasah, Yogyakarta: Pustaka Pelajar.

Moleong, Lexy.J, 2004, Metodologi Penelitian Kualitatif, Bandung : PT .Remaja Rosdakarya.

Muhaimin, 2011, Pemikiran dan Aktualisasi Aktualisasi Pengembangan Pendidikan Islam, Jakarta : Raja Grafindo Persada.

Nasir,Muhammad, 2003, Ikhtisar Penelitian Kwalitatif , Jakarta ; Pustaka Sinar Harapan

Nasution,2006, Manajemen Humas di Lembaga Pendidikan , Konsep, fenomena, dan Aplikasinya, Malang : UMM Press.

Nasution.S, 2003, Metode Research, Jakarta: Bumi Aksara

Page, Arthur.W, 1999, All Bussiness in a Democratic Country Begins with Public Permission an Exist by Public Approavala, dalam Edo Sagara, Journal.

Patton, Michael Quinn, 2006, How to Use Qualitative Methods in Evaluation, terj. Budi Puspo Priyadi, Metode Evaluasi Kualitatif, Yogyakarta : Pustaka Pelajar.

Preedy, Margaret,1984, dalam bukunya Freymer , dkk, 1984, One Hundred 
Good Schools, dan Townsend, dalam Effective Schooling The Community.

Qomar, Mujammil, 2007, Manajemen Pendidikan Islam, Jakarta : Erlangga

Rangkuti, Freddy, 2002, The Power of Brand, Teknik Mengelola Brand Equity dan Strategi Pengembangan Merek, jakarta : PT. Gramedia Pustaka Utama.

Rianto, Yatim, 2001, Metodologi Penelitian Pendidikan, Surabaya :SIC.

Scott M.Cutlip \& Allen Center, 2000, Public relations : Merancang dan Melaksanakan Kegiatan Kehumasan dengan Sukses, (New Jersey: Prentice Hall). 